\title{
Effect of Different Substrate Mixtures on Volatile Aroma Compounds and Antioxidant Activity of Maitake (Grifola frondosa) Mushroom
}

\author{
Mehmet Zahit Aydın",a ${ }^{1, a z g e ~ S u ̈ f e r ~}{ }^{2, b}$, Gökhan Baktemur ${ }^{1, c}$, Flavien Shimira ${ }^{1, d}$, Hatıra Taşkın ${ }^{1, e, *}$ \\ ${ }^{1}$ Department of Horticulture, Faculty of Agriculture, Çukurova University, 01330 Adana, Turkey \\ ${ }^{2}$ Department of Food Engineering, Faculty of Engineering, Osmaniye Korkut Ata University, 80000 Osmaniye, Turkey
}

*Corresponding author

A R T I C L E IN F O A B S T R A C T

Research Article

In the present study, it was aimed to determine the volatile aroma composition and antioxidant activity of Maitake mushroom grown in different substrate mixtures comparatively. Five different substrate mixtures except control were prepared. Total polyphenols and antioxidant activities were specified by Folin-Ciocalteu, Ferric Reducing Antioxidant Power (FRAP) and 1,1-diphenyl-2-

Received : 24/11/2020

Accepted : 02/03/2021 picrylhydrazyl (DPPH) methods. Furthermore, analyzes were carried out in both dried and frozen samples. Head Space Solid Phase Micro Extraction technique combined with Gas ChromatographyMass Spectrometry (GC-MS) was used in the analysis of volatile compounds. In the present study, yield was obtained only from S4 (oak sawdust + wheat stalk + wheat bran at 1:1:1 ratios) and S5 (poplar sawdust + wheat stalk + wheat bran at 1:1:1 ratios) growing mixtures. Therefore, the studies have been continued by comparing only these two mixtures. While the yield in S4 mixture was

Keywords: Grifola frondosa Maitake

Volatile aroma composition Antioxidant activity

Total phenolic content

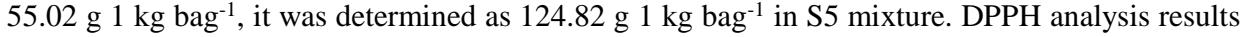
of frozen and dried samples were $7.99 \pm 0.08$ and $8.19 \pm 0.05 \mu \mathrm{mol} \mathrm{TE} \mathrm{g}^{-1} \mathrm{DM}(\mathrm{S} 4)$ and $8.07 \pm 0.09$ and 8.20 $\pm 0.06 \mu \mathrm{mol} \mathrm{TE} \mathrm{g} \mathrm{DM}^{-1}$ (S5) respectively. FRAP results were $1.87 \pm 0.63$ and $6.29 \pm 0.66$ $\mu \mathrm{mol} \mathrm{TE} \mathrm{g}{ }^{-1} \mathrm{DM}(\mathrm{S} 4)$ and $4.24 \pm 0.44$ and $6.45 \pm 0.16 \mu \mathrm{mol} \mathrm{TE} \mathrm{g} \mathrm{g}^{-1} \mathrm{DM}$ (S5) in the same order. In volatile aroma profile analysis, 22 and 32 compounds were detected in S4 and S5, respectively. Ketones were the most found compound groups and its ratio was $68.67 \%$ in S4 and $52.37 \%$ in $\mathrm{S} 5$. The highest percentage among ketones was obtained from 4-nonanone and 3-octanone compounds.

\section{b@ozgesufer@hotmail.com.tr} usflavien@gmail.com

Commons Attribution 4.0 International License

\section{Introduction}

The value of Grifola frondosa (Dicks.) Gray has increased as the importance of this mushroom species was discovered and different expressions have been used to describe its importance over time. It has been named "Maitake" in Japan, "gray tree flower" or "chestnut mushroom" in China, "hen of the woods" or "sheep's head mushroom" in the United States (Chang and Miles, 2004).

Consumers' preferences for food products are related to the stimulation of senses such as sight, taste and smell before and during consumption. Together with many quality features (colour, shape, different chemical content, hardness etc.) flavour characteristics are effective in choosing food (Reineccius, 1994). Aroma of foods is formed as a result of joint action of many volatile compounds and each of them affects the aroma profile differently. These volatile substances, which are present in low concentrations and form the aroma of food, are called "aroma active compounds". These aroma active compounds, which are found at very low amounts such as ppm and ppb in foods, can still be perceived by the human nose. The aroma determination threshold values of each aroma active component are also different. Therefore, aroma analysis is imperative to distinguish every single one of them (Reineccius, 1994; Mayol and Acree, 2001).

Gas Chromatography-Olfactometry (GCO), which uses the human nose as a detector for the determination of aroma active compounds, is widely used (Fuller et al., 1964). Although the human nose has an aroma detection limit of 10-19 moles, many chemical detectors do not. GCO system has two parts: chromatographic as the first part, which includes sampling, extraction, separation and instrumental determination of the aroma components and the second part, which includes the quality, density, timedependent changes and identification of the aroma compounds (Lopetcharat and McDaniel, 2005). The working principle of GCO can be defined as follows; 
injecting of isolated aroma extract into the gas chromatography; chromatographically determining of aroma substances by dividing extract into two equal proportions at column exit and sending it to a chemical detector (FID or MS), determination of aroma qualities by sending to smelling unit. Three different parameters have been determined in GCO: perceived perception or quality of the flavouring agent (for example popcorn), aroma density and retention index of the aroma agent. The retention index of a volatile indicates the location of flavouring agent on the chromatogram. The odour density of the aroma substance is expressed according to a predetermined 9 or 10-point scale (Friedrich and Acree, 1998; Van Ruth, 2001; Hış11, 2004; Lopetcharat and McDaniel, 2005). The most common methods used for collecting data in GCO: Dilution Analysis, Time-Intensity and Posterior Intensity (Güneşer and Yüceer, 2010).

Oxidation has an important place in providing the energy required for nutrition in living organisms. Besides, free radicals in the living body can play an important role in diseases such as cancer, arthritis and arteriosclerosis (Halliwell and Gutteridge, 1984). However, there is an important balance between free radicals and antioxidants. Maintaining this balance has been an essential element for living organisms. There are some synthetic antioxidants produced to reduce damage of free radicals in the living body. However, these antioxidants are suspected of causing liver damage. Therefore, it will be essential for people to use natural antioxidants that can protect from free radicals and prevent diseases, rather than synthetic antioxidants that cause such chronic and serious damage (Qi et al., 2005). Disruption of this balance causes cellular protein, DNA and lipids to be oxidizable and deterioration may occur. A large number of antioxidant substances have been isolated from various plant materials such as vegetables, fruits, cereals and herbs (Ramarathnam et al., 1995). In addition, mushrooms have shown antioxidant properties and this property of some mushroom species has been used for centuries.

Although many studies have been carried out on the nutritional and medicinal value of Maitake mushroom (Chang and Miles, 2004; Hsieh and Yang, 2004; Tabata et al., 2004; Barreto et al., 2008; Svagelj et al., 2008; Montoya et al., 2012; Sato et al., 2017; Song et al., 2018), studies on volatile aroma compounds of this species are limited (Rapior et al., 1996; Zhou et al., 2015). Also, the aroma of this mushroom has been identified as "hydrocyanic acid, cherry laurel nut oil, then blue cheese, herbaceous, whey, moldy, wild hyacinth, cereal, hyacinth, yeast, cereals then citrus" based on previous studies organized by Jong and Birmingham (1993) (Badcock, 1939; Maga, 1976; Schindler and Schmid, 1982; Gallois et al., 1990).

Production of volatile compounds by mushrooms and obtaining of taste depends on the composition of the growing mixture, growing conditions, genetic diversity of strains and subjectivity of sensory perception. Modification of culture conditions, especially selection of nitrogen and carbon sources, affects the composition of mushroom odour profile at least quantitatively (Jong and Birmingham, 1993).

The aim of this study is to determine and compare the volatile aroma composition and antioxidant activity of Maitake mushroom obtained from different growing mixtures.

\section{Material and Method}

In the present study, WC 828 Maitake mushroom strain (Mushroom Spawn Lab of Penn State University, US) was used as the main stock. Then, mycelia propagation was performed using Potato Dextrose Agar (PDA) nutrient medium from these main petri dishes at the Prof. Dr. Saadet Büyükalaca laboratory of Çukurova University (Adana, Turkey). Wheat grains were preferred for obtaining spawn. Oak sawdust, poplar sawdust, wheat stalk and wheat bran were chosen in the preparation of mushroom growing mixtures.

\section{Obtaining of Spawn}

In the first stage of obtaining spawn, main stock of Maitake mushroom strain mycelia (WC 828 strain) was propagated in Potato Dextrose Agar (PDA) nutrient medium. For this purpose, $39 \mathrm{~g} \mathrm{~L}^{-1}$ of instant PDA medium was weighed and $\mathrm{pH}$ was adjusted to 5.4. The prepared nutrient media were sterilized in an autoclave at $121^{\circ} \mathrm{C}$ and $1.2 \mathrm{~atm}$ for 15 minutes together with materials used. The nutrient media removed from the autoclave was cooled in the sterile bench for a while and then poured into sterile plastic petri dishes. Then, one of the Maitake mycelia stock was opened in the sterile bench and $1 \mathrm{~cm}$ pieces were taken using sterile forceps and scalpels. Cultures obtained were kept in an incubation room in dark condition until entire mycelia development in petri dishes. Following mycelia development, wheat grains were boiled and dried. Then, they were filled into large glass jars and sterilized in the autoclave at $121^{\circ} \mathrm{C}$ and $1.2 \mathrm{~atm}$ for 15 minutes. The bottles removed from the autoclave were placed in the sterile bench for cooling. The mycelia in each petri dish were divided into eight pieces and a piece was placed on each side of each wheat-filled jar. Then, the jars were shaken every day for obtaining homogeneous mycelia development in the jar.

\section{Preparation of Substrate Mixtures}

In the preparation of substrate mixtures; oak sawdust (OS), poplar sawdust (PS), wheat stalk (WS) and wheat bran (WB) were used by mixing at different proportions. In the experiments, 2 volumes of oak sawdust and 1 volume of wheat bran (2 OS + WB) known as successful in the cultivation of mushroom species were used as control.

Other mixtures were prepared as follows:

C : 2 oak sawdust +1 wheat bran $(2 \mathrm{OS}+\mathrm{WB})$

S1 : 2 poplar sawdust +1 wheat bran $(2 \mathrm{PS}+\mathrm{WB})$

S2 : 2 wheat stalk +1 wheat bran $(2 \mathrm{WS}+\mathrm{WB})$

S3 : 1 oak sawdust +1 poplar sawdust +1 wheat bran $(\mathrm{OS}+\mathrm{PS}+\mathrm{WB})$

S4 : 1 oak sawdust +1 wheat stalk +1 wheat bran $(\mathrm{OS}$ + WS + WB)

S5 : 1 poplar sawdust +1 wheat stalk +1 wheat bran $(\mathrm{PS}+\mathrm{WS}+\mathrm{WB})$

All materials were first grinded, then kept in waterfilled containers for a certain time until their moisture content was appropriate (at least $70 \%$ moisture). After moistening process was completed, adjustments were performed by measuring of $\mathrm{pH}$ of the growing mixtures (67) and adding lime. 


\section{Sterilization and Mycelia Inoculation}

The prepared substrate mixtures were filled into high temperature resistant polypropylene bags as $1 \mathrm{~kg}$. The mouths of the bags were tied with rubber bands and were sterilized for 1 hour in the autoclave at $121^{\circ} \mathrm{C}$ and $1.2 \mathrm{~atm}$ for sterilization. Since experiments on obtaining spawn by wrapping mycelia to wheat grains were not successful, the mycelia inoculation process was carried out by cutting the mycelia developed in the PDA medium into pieces and placing these pieces into the growing mixtures directly with sterile forceps.

\section{Mycelia Development and Harvest}

Growing bags inoculated with mycelia were placed in mushroom growing rooms having $22 \pm 1^{\circ} \mathrm{C}$ of temperature and $70-80 \%$ of humidity for mycelia development. After the mycelia development was achieved, the temperature was reduced to $18 \pm 1^{\circ} \mathrm{C}$. Following the fruiting body stage, the humidity was kept at $90-95 \%$ to prevent drying of the growing mixtures and 40-watt fluorescent lamps were used for 12 hours and 200 lux lighting was provided. When the mycelia development were observed in the growing mixtures (from 35 to 42 days), the bags were cut with a sterile scalpel in $5 \mathrm{~cm}$ wide to stimulate the formation of the primordia and also the mouthes of bags were opened. When most of the mushrooms were the same size, samples were harvested.

\section{Extraction of Bioactive Substances}

For the extraction process, method of Bennett et al. (2011) was used in a modified form. $25 \mathrm{~mL}$ of $80 \%$ methanol was added onto one gram of mushroom sample. The mixture was shaken by vortex for 15 seconds, then kept in an ultrasonic water bath at $25^{\circ} \mathrm{C}$ (J.P. Selecta Ultrasons HD, Barcelona) for 20 minutes. Following this process, samples were centrifuged for 15 minutes in a centrifuge at $3500 \mathrm{rpm}$ (Hettich Zentrifugen, Tuttlingen, Germany). Moreover, they were filtered with filter paper and made ready for spectrophotometric analysis. Relevant analyzes were carried out on the same day and tests were performed with four repetitions. $80 \%$ methanol was used as a control in all methods used except the FRAP method.

\section{Total Phenolic Compound Determination}

For determination of the total amount of phenolic compounds, $0.5 \mathrm{~mL}$ of Folin-Ciocalteu reagent was added to $0.5 \mathrm{~mL}$ of extract. Then, $3 \mathrm{~mL}$ of $10 \% \mathrm{Na}_{2} \mathrm{CO}_{3}$ solution was added and the mixture was kept in the dark condition for 30 minutes. The total phenolic compounds of the samples whose absorbances were measured in the spectrophotometer (Shimadzu, UV 1800, Japan) at $760 \mathrm{~nm}$ were calculated as gallic acid equivalent (GAE) $\mathrm{g}^{-1}$ dry matter (DM) (modified from Li et al., 2015).

\section{Antioxidant Activity Determination (DPPH Method)}

A solution of 1,1-diphenyl-2-picrylhydrazyl (DPPH) prepared at a concentration of $2 \mathrm{~mL}$ of $0.025 \mathrm{~g} \mathrm{~L}^{-1}$ was added to $0.1 \mathrm{~mL}$ of mushroom extract and the samples were kept in the dark condition for 30 minutes. Readings were performed in the spectrophotometer (Shimadzu, UV 1800, Japan) at $519 \mathrm{~nm}$ and the results were expressed as $\mu \mathrm{mol}$ trolox equivalent (TE) $\mathrm{g}^{-1} \mathrm{DM}$ (modified from Aghraz et al., 2018).

\section{Antioxidant Activity Determination (FRAP Method)}

To prepare the FRAP (Ferric Reducing Antioxidant Power) reagent used in the experiment, $10 \mathrm{mmol} \mathrm{L}^{-1} 2.5 \mathrm{~mL}$ TPTZ solution prepared in $40 \mathrm{mmol} \mathrm{L}^{-1} \mathrm{HCl}$ solution, 2.5 $\mathrm{mL} 20 \mathrm{mmol} \mathrm{L}^{1} \mathrm{FeCl}_{3}$ solution and $25 \mathrm{~mL} 0.1 \mathrm{~mol} \mathrm{~L}^{1}$ acetate buffer $(\mathrm{pH}=3.6)$ were used. $2 \mathrm{~mL}$ of FRAP reagent was added to $0.3 \mathrm{~mL}$ of extract and the volume was completed to $10 \mathrm{~mL}$ with distilled water. Absorbances of the samples kept in the dark condition for 10 minutes were measured in the Spectrophotometer (Shimadzu, UV 1800, Japan) at $593 \mathrm{~nm}$. In addition, $2 \mathrm{~mL}$ of FRAP reagent was completed with 10 $\mathrm{mL}$ of distilled water and this solution was used as a blank sample. The results were expressed as $\mu \mathrm{mol}$ TE $\mathrm{g}^{1} \mathrm{DM}$ (Szydłowska-Czerniak et al., 2008).

\section{Volatile Aroma Compounds Analysis}

Volatile aroma composition was determined using Gas Chromatography Mass Spectrophotometer (GC/MS) combined with Head Space-Solid Phase Micro Extraction (HS-SPME) technique. Aroma analysis was carried out with the technique advanced by Palazzolo et al. (2017) containing minor modifications. For this, $5 \mathrm{~g}$ of Maitake mushroom samples were extracted at $30^{\circ} \mathrm{C}$ for 30 minutes. Analyzes were carried out using $1 \mathrm{~cm} 50 / 30 \mu \mathrm{m}$ Divilbenzene Carboxen/Polydimethylsiloxane (DVB/CAR/PDMS) StableFlex (Supelco, Bellefonte, PA, USA) fiber at $270^{\circ} \mathrm{C}$ for 60 minutes. For the extraction, $50 / 30 \mu \mathrm{m}$ fiber was used, which is recommended by many researchers because of its sensitivity and efficiency (Tian et al., 2016; Politowicz et al., 2018; Li et al., 2019). Volatile aroma compounds were determined by Agilent 7000 Triple Quatro MSD Mass Spectrometer equipped with Agilent 7890B brand gas chromatography. Separation of volatile compounds was performed using a DB-WAX capillary column $(60 \mathrm{~m} \times 0.25 \mathrm{~mm} \times 0.5 \mu \mathrm{m})$ at $1.5 \mathrm{~mL}$ $\mathrm{min}^{-1}$ flow rate of carrier gas (helium). The oven temperature was first at $40^{\circ} \mathrm{C}$ for 4 minutes, then increased to $90^{\circ} \mathrm{C}$ to $3^{\circ} \mathrm{C}$ per minute, then to $130^{\circ} \mathrm{C}$ at $4^{\circ} \mathrm{C}$ per minute and $240^{\circ} \mathrm{C}$ to $5^{\circ} \mathrm{C}$ per minute, finally at $240^{\circ} \mathrm{C}$ for 8 minutes. The same oven temperature schedule was applied for MSD. MSD conditions were as follows: ionization energy $70 \mathrm{Ev}$, mass range $\mathrm{m} / \mathrm{z}$ 30-300 a.m.u, scan rate 2.0 $\mathrm{scan} / \mathrm{sec}$, interface temperature $250^{\circ} \mathrm{C}$ and source temperature $180^{\circ} \mathrm{C}$. The diagnosis of peaks was performed by injecting a standard solution in the samples. In compounds not having standard, it was carried out by comparing their mass spectra with the mass spectra in computer memory (W9, NIST 11, flavour 2). Retention indices (RI) of all identified compounds were calculated using n-alkane series. All analyses were performed in triplicate (Selli et al., 2006; Cho et al., 2007).

\section{Statistical Analysis}

The \% results of the volatile aroma compounds of Maitake mushrooms obtained in different substrate mixtures were determined in the JMP package program according to the random plot design.

\section{Results and Discussion}

In the present study, fruiting body formation was observed only in S4 (1 OS + 1 WS + 1 WB) and S5 (1 PS + $1 \mathrm{WS}+1 \mathrm{WB}$ ) growing mixtures. Therefore, only these two substrate mixtures could be compared in the study. While first flash mushroom yield was $55.02 \mathrm{~g} \mathrm{~kg} \mathrm{bag}^{-1}$ in the $\mathrm{S} 4$ 
mixture, it was determined as $124.82 \mathrm{~g} \mathrm{~kg} \mathrm{bag}^{-1}$ in the S5 mixture. In the study of Song et al. (2018), the first flash mushroom yield varied between 31.75 and $134.25 \mathrm{~g} \mathrm{bag}^{-1}$ (each bag $800 \mathrm{~g}$ ). When we calculated yield values for 1000 $\mathrm{g}(1 \mathrm{~kg})$ to compare with our study, the yield ranged from 39.68 to $167.81 \mathrm{~g} \mathrm{bag}^{-1}$. In our study, the yield was between 55.02 and $124.82 \mathrm{~g} \mathrm{bag}^{-1}$. Our results seem within an acceptable range.

Reasons for not obtaining yield from the other substrate mixtures (Control, S1, S2 and S3) during the study may be detailed as follows: (i) the cultivation of Maitake mushroom was the first experience for us (ii) temperature was above seasonal norms (This temperature increase should not be considered as affecting the growing room. Because our experiments were carried out in climate-controlled mushroom growing rooms. The temperature increases revealed insect/pest's problem. With the increase of temperature, pests were activated earlier. Pest entrance to the mushroom growing rooms can be explained by the fact that our mushroom growing rooms are located in the university building, which is an educational institution and there are rooms used for different aims in the corridor and student entrance to the corridor).

\section{Total Phenolic Compounds}

While the total bioactive amounts of the frozen and dry samples of S4 substrate mixture were $5.06 \pm 0.14$ and $17.47 \pm 1.00 \mathrm{mg} \mathrm{GAE} \mathrm{g}^{-1} \mathrm{DM}$, respectively, they were $3.45 \pm$ 0.07 and $29.26 \pm 1.34 \mathrm{mg} \mathrm{GAE} \mathrm{g}^{-1} \mathrm{DM}$ in S5 substrate mixture. When the results were examined, it was observed that the drying process increases the total amount of bioactive substance in both sample groups. In addition, it was observed that the effect of drying process on the phenolic content of mushrooms produced in S5 is more than S4. This situation reveals the fact that more phenolic compounds are synthesized or produced in S5 with the effect of heat.

When the literature on the total phenolic content of Maitake and different mushroom species was examined, Mau et al. (2002) found that the total phenol content in dried samples of 4 mushroom species (Dictophora indusiata, Grifola frondosa, Hericium erinaceus and Tricholoma giganteum) ranged from 7.61 to $16.28 \mathrm{mg} \mathrm{g}^{-1}$. Maitake mushroom ranked second with $12.31 \mathrm{mg} \mathrm{g}^{-1}$. Mau et al. (2004) investigated the total phenol content of mycelia of freezedried Grifola frondasa, Morchella esculenta and Termitomyces albuminosus mushroom species and they found the lowest content in Maitake mushroom with $1.59 \mathrm{mg} \mathrm{g}^{-1}$ compared to the other two species. In a study carried out by Yeh et al. (2011), total phenol contents were determined between 15.28 and $42.30 \mathrm{mg} \mathrm{g}^{-1}$ in ground mushroom powder samples belonging to two different strains of dried Maitake depending on the strains and extraction method. Shin and Lee (2014) investigated the effect of hydrothermal extraction on the total phenol content of Maitake mushroom and the total phenol content was between 12.16 and $13.61 \mathrm{mg} \mathrm{GAE} \mathrm{g}^{-1}$ Maitake powder. Yildiz et al. (2015) determined that the total phenolic amount of $G$. frondosa was higher than Lentinula edodes and Hericium erinaceus and less than Ganoderma lucidum and Morchella esculenta. Total phenolic contents of some mushroom species such as Agaricus bisporus, Flammulina velutipes, Schizophyllum commune, G. frondasa, Hypsizygus tessellatus, Pleurotus eryngii and Pleurotus ostreatus obtained from market were detected separately in water and methanol extracts by Muhammad Ezzudin et al. (2019). Among nine mushroom species, the highest total phenolic content in both extracts was recorded in Maitake mushroom with $129.44 \mu \mathrm{g} \mathrm{GAE} \mathrm{g}^{-1}$. The results of total phenol and antioxidant activity analysis performed on 25 different mushroom species by Butkhup et al. (2018) were presented in Table 1 and the phenolic content ranged between $0.72 \mathrm{~g} \mathrm{GAE} \mathrm{kg}^{-1}$ dry weight (Alpova trappei) and $8.84 \mathrm{~g} \mathrm{GAE}$ $\mathrm{kg}^{-1}$ dry weight (Termitomyces clypeatus). Although this study (conducted on dried mushrooms) did not include Maitake mushroom, when we compared with the results of the dried samples of our study (results of both frozen and dried samples are presented in our study), values obtained by us in Maitake mushroom were higher than all data determined by Butkhup et al. (2018) in 25 different mushroom species with $17.47 \pm 1.00 \mathrm{mg} \mathrm{GAE} \mathrm{g}^{-1} \mathrm{DM}$ in S4 and $29.26 \pm 1.34 \mathrm{mg} \mathrm{GAE}$ $\mathrm{g}^{-1} \mathrm{DM}$ in S5. Furthermore, our results were higher than the most of data obtained in Maitake by different researchers such as $12.31 \mathrm{mg} \mathrm{g}^{-1}$ (in dried samples) by Mau et al. (2002), 1.59 $\mathrm{mg} \mathrm{g}^{-1}$ (in freeze-dried samples) by Mau et al. (2004), 15.28 and $42.30 \mathrm{mg} \mathrm{g}^{-1}$ (in dried samples) by Yeh et al. (2011) in two different strains and 12.16 and $13.61 \mathrm{mg} \mathrm{GAE} \mathrm{g}^{-1}$ Maitake powder (in dried samples) by Shin and Lee (2014).

\section{Antioxidant Activity}

When the results of antioxidant activity analysis performed with different methods were evaluated, it was observed that obtained data by the DPPH method were higher than those obtained by the FRAP method in all samples. This proves that the amount of antioxidant molecules that can reduce the hydrogen ion in $G$. frondosa is higher than the antioxidants that reduce iron. DPPH analysis results of frozen and dry samples for S4 and S5 mixtures were $7.99 \pm 0.08$ and $8.19 \pm 0.05 \mu \mathrm{mol} \mathrm{TE} \mathrm{g}^{-1} \mathrm{DM}$ (S4) and 8.07 \pm 0.09 and $8.20 \pm 0.06 \mu \mathrm{mol} \mathrm{TE} \mathrm{g}{ }^{-1} \mathrm{DM}$ (S5). FRAP results were calculated in the same order as follows; $1.87 \pm 0.63$ and $6.29 \pm 0.66 \mu \mathrm{mol} \mathrm{TE} \mathrm{g}^{-1} \mathrm{DM}$ (S4) and $4.24 \pm 0.44$ and $6.45 \pm 0.16 \mu \mathrm{mol} \mathrm{TE} \mathrm{g}^{-1} \mathrm{DM}$ (S5). Our findings showed that the antioxidant activity of samples grown in S5 are higher than those in S4. In addition, while the drying process did not have a significant enhancing effect on bioactives capable of reducing hydrogen ion, it was determined that these bioactives increased approximately 2fold in terms of those that reduce the iron ion.

When the previous studies were examined, it was concluded that $G$. frondosa was richer in antioxidants that could reduce iron than G. lucidum, M. esculenta, L. edodes and H. erinaceus (Yildiz et al., 2015). In a study carried out in Dictyophora indusiata, G. frondosa, H. erinaceus and Tricholoma giganteum by Mau et al. (2002), scavenging effects on DPPH radicals at $6.4 \mathrm{mg} \mathrm{mL}^{-1}$ were found to be $92.1 \%$ in D. raindusiata and $63.2 \%$ in other mushroom species. At $40 \mathrm{mg} \mathrm{mL}^{-1}$, scavenging effects were recorded as $75.0 \%, 69.4 \%, 39.6 \%$ and $47.4 \%$ for $D$. raindusiata, $H$. erinaceus, $G$. frondosa and $T$. giganteum, respectively. Chelating effect on iron ions at $24 \mathrm{mg} \mathrm{mL}-1$ was detected as $91.9 \%$ for D. raindusiata and between 46.4 and $52.0 \%$ for other mushroom species. Mau et al. (2004) determined scavenging effects of mycelia of $G$. frondosa, M. esculenta and $T$. albuminosus on DPPH radicals at $10 \mathrm{mg} \mathrm{mL}^{-1}$ between 78.8 and $94.1 \%$. 
Table 1. Results of Total phenolic compounds and antioxidant activity analysis performed on different mushroom species by Butkhupet al. (2018)

\begin{tabular}{|c|c|c|c|}
\hline Species & Total phenol (g GAE kg-1 DM) & DPPH $(\%)$ & FRAP (g Fe (II) $\left.\mathrm{kg}^{-1} \mathrm{DM}\right)$ \\
\hline Amanita princeps & 1.68 & 59.40 & 3.01 \\
\hline A. hamibapa & 8.53 & 71.75 & 7.54 \\
\hline Lactarius volemus & 3.61 & 66.75 & 0.92 \\
\hline Russula luteotacta & 4.63 & 81.24 & 7.53 \\
\hline R. emetica & 1.71 & 46.31 & 0.20 \\
\hline R. alboareolata & 4.68 & 62.71 & 2.66 \\
\hline R. galochroides & 2.38 & 69.76 & 3.86 \\
\hline R. cyanoxantha & 2.91 & 78.74 & 3.03 \\
\hline$R$. nigricans & 2.31 & 51.90 & 0.32 \\
\hline$R$. densfolia & 5.62 & 55.43 & 2.14 \\
\hline R. delica & 4.83 & 75.72 & 3.74 \\
\hline$R$. violeipes & 2.26 & 63.59 & 3.34 \\
\hline Termitomyces fuliginosus & 6.31 & 72.34 & 4.47 \\
\hline T. clypeatus & 8.84 & 83.07 & 9.79 \\
\hline Tricholoma crassum & 2.56 & 64.18 & 0.37 \\
\hline Volvariella volvacea & 8.49 & 86.60 & 8.42 \\
\hline Astraeus hygrometricus & 2.33 & 45.72 & 0.41 \\
\hline Alpova trappei & 0.72 & 36.75 & 0.24 \\
\hline Auricularia auricula & 0.95 & 40.94 & 0.10 \\
\hline Cantharellus cibarius & 1.41 & 64.10 & 1.94 \\
\hline Craterellus aureus & 2.34 & 59.91 & 4.12 \\
\hline Lentinula squarrosulas & 5.42 & 71.68 & 2.64 \\
\hline L. polychrous & 5.35 & 85.43 & 3.91 \\
\hline L. edodes & 2.21 & 63.44 & 2.50 \\
\hline L. giganteus & 1.46 & 56.90 & 3.65 \\
\hline
\end{tabular}

dw: dry weight

These three species did not have a scavenging effect on hydroxyl radicals. Chelating effect on iron ions was found to be high at $10 \mathrm{mg} \mathrm{mL}$ (90.3-94.4\%). In a study conducted by Yeh et al. (2011) on the effect of different extraction methods on antioxidant activity in two strains of Maitake, while DPPH results were found to be $3.51 \mathrm{mg}$ $\mathrm{mL}^{-1}$ in ethanol extract, $19.42 \mathrm{mg} \mathrm{mL}^{-1}$ in cold water and $17.36 \mathrm{mg} \mathrm{mL}^{-1}$ in hot water in $\mathrm{T} 1$ strain, they were 5.07, 10.25 and $9.27 \mathrm{mg} \mathrm{mL}^{-1}$ in ethanol, cold and hot water, respectively in T2 strain. Shin and Lee (2014) investigated the effect of hydrothermal extraction on the antioxidant activity of Maitake mushroom and DPPH values were determined as $37.13 \%$ at $121^{\circ} \mathrm{C}$ in 30 minutes, $55.36 \%$ in 60 minutes, $46.76 \%$ in 30 minutes at $130^{\circ} \mathrm{C}, 62.04 \%$ in 60 minutes, $46.81 \%$ at $140^{\circ} \mathrm{C}$ in 30 minutes, $57.19 \%$ in 60 minutes, $53.29 \%$ in 30 minutes at $150^{\circ} \mathrm{C}$ and $65.85 \%$ in 60 minutes. The antioxidant activity was determined in some mushroom species (A. bisporus, F. velutipes, $S$. commune, G. frondosa, H. tessellatus, $P$. eryngii and P. ostreatus) obtained from market in water and methanol extract separately using DPPH and FRAP methods by Muhammad Ezzudin et al. (2019). EC50 value of DPPH reducing activity could not be determined for Maitake mushroom in water. However, it was detected as 39.46 and $14.63 \mathrm{mg} \mathrm{mL}$ 1 in FRAP method in water and methanol extract, respectively. When the study conducted by Butkhup et al. (2018) on 25 mushroom species was examined (Table 1), DPPH values were between $40.94 \%$ (Auricularia auricula) and $86.60 \%$ (Volvariella volvacea) and FRAP values varied between $0.10 \mathrm{~g} \mathrm{Fe}$ (II) $\mathrm{kg}^{-1}$ dry weight (A. auricula) and $9.79 \mathrm{~g} \mathrm{Fe}$ (II) $\mathrm{kg}^{-1}$ dry weight (Termitomyces clypeatus). Comparing the literature data with the values of our study seems difficult since obtained data were in different units. However, in our study and also in the literature, a significant level of antioxidant activity was detected in $G$. frondosa mushroom.

\section{Volatile Aroma Analysis}

In the experiment, 22 and 32 volatile components were detected in S4 (1 OS + $1 \mathrm{WS}+1 \mathrm{WB})$ and S5 (1 PS + 1 $\mathrm{WS}+1 \mathrm{WB}$ ) growing mixtures (Table 2 ). These volatile compounds were classified as aldehyde, hydrocarbon, alcohol, ketone, volatile acid, ester, terpene and other compounds. Volatiles obtained from mushroom samples grown in S4 were $2.51 \%$ aldehyde, $5.51 \%$ hydrocarbon, $19.69 \%$ alcohol, $68.62 \%$ ketone, $0.79 \%$ volatile acid, $0.20 \%$ ester, $0.32 \%$ terpene and $0.84 \%$ other components. These percentages were $13.06 \%$ aldehyde, $3.21 \%$ hydrocarbon, $25.49 \%$ alcohol, $52.37 \%$ ketone, $2.06 \%$ volatile acid, $0.21 \%$ ester, $0.32 \%$ terpene and $2.32 \%$ other components in S5. Hydrocarbons and ketones were detected at a higher rate in S4, while aldehydes, alcohols, volatile acids and other components were higher in S5. Only 1 compound was detected for ester and terpene each and the ratio was the same or very close.

There is not much information in the literature regarding the volatile aroma components of Maitake mushroom. In a study carried out in frozen Maitake mushrooms by Rapior et al. (1996); 1-octen-3-ol, 3methylbutan-2-one, methyl 2,4-dihydroxybenzoate, heptane, $\delta$-cadinene, benzyl alcohol and benzyl aldehyde were detected. Since we could not reach the full text of the study, we do not have any information about the content of growing mixtures used in the cultivation of mushroom. In another study conducted by Zhou et al. (2015) on dry Maitake samples obtained from the market, 1-octen-3-ol, 
nerolidol, spathulenol, $\alpha$-cadinol, 2-octanone, 1-octen-3one, 2-nonanone, 2-decanone, 3-nonen-2-one, 2undecanone, 3-decen-2-one, octanal, (E)-2-heptenal, nonanal, 2-octenal, (2E, 4E)-2,4-decadienal, 1-isoamyl-2formyl pyrrol, 1-(2-methylbutyl)-2-formyl, benzaldehyde, benzaldehyde, 4-methyl, phenylacetaldehyde, anethole, naphthalene, 2-methyl-butylated, hydroxytoluene, $\mathrm{N}$ ethylpropionanilide, ortho-cresol 2,4-di-tert-butylphenol, $\gamma$-muurolene, cedran-8-ol, $\alpha$-copaene, (3E) -3-ethyl-2methyl-1,3-hexadiene, octylformate, diethylphthalate, hexanedioicacid, bis (2-ethylhexyl) ester and DL-menthol compounds have been identified. Likewise, since samples were obtained from the market, there is no information about mixtures in which they are grown.

Among the volatiles obtained from these two studies and the compounds detected in our study, the common ones were mostly 1-octen-3-ol and benzyl aldehyde. However, interestingly, these two volatiles were detected at a low percentage in our study. It is known that the volatile aroma components of cultivated mushrooms vary according to strains, growing mixtures, which development stage of mushroom used in analysis, whether the samples are frozen, dried or fresh and method used.

Table 2. Volatile aroma compositions of Maitake mushroom samples obtained from two different growing mixtures

\begin{tabular}{|c|c|c|c|}
\hline Volatile compounds & RI & S4 & S5 \\
\hline $\begin{array}{l}\text { Aldehyde } \\
\text { Acetaldehyde } \\
\text { Pentanal } \\
\text { 3-methyl-butanal } \\
\text { Hexanal } \\
\text { Octanal } \\
\text { Benzaldehyde } \\
\text { Benzeneacetaldehyde } \\
\alpha \text {-ethylidenbenzeneacetaldehyde }\end{array}$ & $\begin{array}{c}716 \\
929 \\
930 \\
1077 \\
1291 \\
1525 \\
1612 \\
1939\end{array}$ & $\begin{array}{l}0.63 \mathrm{~b} \\
\mathrm{nd} \\
1.09 \mathrm{~b} \\
0 \\
0 \\
0.79 \mathrm{~b} \\
0 \\
0 \\
2.51 \\
\end{array}$ & $\begin{array}{c}1.45 \mathrm{a} \\
0.37 \\
6.02 \mathrm{~b} \\
0.31 \\
0.38 \\
2.12 \mathrm{a} \\
0.38 \\
2.03 \\
13.06\end{array}$ \\
\hline $\begin{array}{l}\text { Hydrocarbon } \\
\text { 1-octene } \\
\text { Ethylbenzene } \\
\text { p-xylene } \\
\text { o-xylene } \\
\text { 1,3-dichlorobenzene } \\
\text { Toplam } \\
\text { Alcohol } \\
\text { 3-methyl-1-butanol } \\
\text { 1-hexanol } \\
\text { 3-octanol } \\
\text { 1-octen-3-ol } \\
\text { 1-octyn-3-ol } \\
\text { 3-(methylthio)-1-propanol } \\
\text { Phenylethyl alcohol }\end{array}$ & $\begin{array}{l}1207 \\
1359 \\
1394 \\
1427 \\
1532 \\
1723 \\
1923\end{array}$ & $\begin{array}{c}9.71 \mathrm{~b} \\
0.72 \mathrm{~b} \\
4.01 \mathrm{a} \\
0.42 \mathrm{~b} \\
- \\
0.55 \mathrm{~b} \\
4.28 \mathrm{~b} \\
19.69 \\
\end{array}$ & $\begin{array}{c}13.47 \mathrm{a} \\
1.33 \mathrm{a} \\
3.06 \mathrm{~b} \\
0.95 \mathrm{a} \\
0.44 \\
0.81 \mathrm{a} \\
5.88 \mathrm{a} \\
25.94 \\
\end{array}$ \\
\hline $\begin{array}{l}\text { Ketone } \\
\text { 3-octanone } \\
\text { Acetoin } \\
\text { 4-nonanone } \\
\text { Total } \\
\text { Volatile acid } \\
\text { Acetic acid } \\
\text { 3-methylbutanoic acid } \\
\text { 3-hydroxydodecanoic acid }\end{array}$ & $\begin{array}{l}1211 \\
1280 \\
1356\end{array}$ & $\begin{array}{c}32.59 \mathrm{a} \\
0.86 \mathrm{a} \\
35.17 \mathrm{a} \\
68.62\end{array}$ & $\begin{array}{c}22.80 \mathrm{~b} \\
1.44 \mathrm{a} \\
28.13 \mathrm{~b} \\
52.37\end{array}$ \\
\hline $\begin{array}{l}\text { Ester } \\
\text { 2,5-octadecadiynoic acid, methyl ester } \\
\text { Terpene } \\
\text { trans-geranylacetone } \\
\text { Other compounds } \\
\text { 2-propenoic acid, 3-[2-(aminocarbonyl)phenyl]- } \\
\text { 2,7-dimethyl-4,5-octanediol } \\
\text { Methyl N-hydroxybenzenecarboximidoate } \\
\text { Methyl 8-[(1R,2R)-2-[(1S,2R)-2 hexylcyclopropyl]cyclopropyl]octanoate }\end{array}$ & $\begin{array}{l}1865 \\
1420 \\
1446 \\
1734 \\
2031\end{array}$ & $\begin{array}{c}- \\
0.27 \mathrm{~b} \\
0.57 \mathrm{a} \\
0 \\
0.84\end{array}$ & $\begin{array}{c}0.24 \\
1.23 \mathrm{a} \\
0.65 \mathrm{a} \\
0.2 \\
2.32\end{array}$ \\
\hline
\end{tabular}


Table 3. Taste and fragrance definitions of compounds obtained from two different growing mixtures in Maitake mushroom in the study

\begin{tabular}{|c|c|c|}
\hline Aroma compounds & Description & Reference \\
\hline \multicolumn{3}{|l|}{ Aldehyde } \\
\hline Acetaldehyde & sweet,pungent & Curioni ve Bosset (2002) \\
\hline Pentanal & chemical & Curioni ve Bosset (2002) \\
\hline 3-methyl-butanal & malty & Zhang ve ark (2018) \\
\hline Hexanal & $\begin{array}{l}\text { woody, vegetable } \\
\text { flavour, cut grass like }\end{array}$ & $\begin{array}{l}\text { Li ve ark (2019), Cho ve } \\
\text { ark (2007) }\end{array}$ \\
\hline Octanal & cucumber, citrus plastic & Aisala ve ark (2019) \\
\hline Benzaldehyde & almond, fruity, nuty & Li ve ark (2019) \\
\hline Benzeneacetaldehyde & - & \\
\hline$\alpha$-ethylidenbenzeneacetaldehyde & - & \\
\hline \multicolumn{3}{|l|}{ Hydrocarbon } \\
\hline 1-octene & - & \\
\hline Ethylbenzene & - & \\
\hline p-xylene & rotten, onion & Aisala ve ark (2019) \\
\hline o-xylene & - & \\
\hline 1,3-dichlorobenzene & - & \\
\hline \multicolumn{3}{|l|}{ Alcohol } \\
\hline 3-Methyl-1-butanol & cheese & Culleré ve ark (2010) \\
\hline 1-hexanol & green & Cho ve ark (2007) \\
\hline 3-octanol & $\begin{array}{c}\text { earthy, mushroom-like, } \\
\text { herbal, buttery }\end{array}$ & $\begin{array}{l}\text { Xu ve ark (2019), Cho ve } \\
\operatorname{ark}(2007)\end{array}$ \\
\hline 1-octen-3-ol & $\begin{array}{l}\text { earthy, mushroom-like, } \\
\text { green }\end{array}$ & $\begin{array}{c}\text { Xu ve ark (2019), Cho ve } \\
\operatorname{ark}(2007)\end{array}$ \\
\hline 1-octyn-3-ol & - & \\
\hline 3-(methylthio)-1-propanol & heated onion & Zhang ve ark (2018) \\
\hline Phenylethyl alcohol & floral, sweet & Cho ve ark (2007) \\
\hline \multicolumn{3}{|l|}{ Ketone } \\
\hline 3-octanone & mushroom, soil, potato & Aisala ve ark (2019) \\
\hline Acetoin & buttery, creamy, moldy & $\begin{array}{l}\text { Pionnier ve Hugelshofer } \\
\text { (2006) }\end{array}$ \\
\hline 4-nonanone & - & \\
\hline \multicolumn{3}{|l|}{ Volatile acid } \\
\hline Acetic acid & sour & Zhang ve ark (2018) \\
\hline 3-methylbutanoic acid & sweaty & Zhang ve ark (2018) \\
\hline 3-hydroxydodecanoic acid & - & \\
\hline \multicolumn{3}{|l|}{ Ester } \\
\hline 2,5-octadecadiynoic acid, methyl ester & - & \\
\hline \multicolumn{3}{|l|}{ Terpene } \\
\hline trans-geranylacetone & moldy, leaves, plastic & Aisala ve ark (2019) \\
\hline \multicolumn{3}{|l|}{ Other compounds } \\
\hline 2-propenoic acid, 3-[2-(aminocarbonyl)phenyl]- & - & \\
\hline 2,7-dimethyl-4,5-octanediol & - & \\
\hline Methyl N-hydroxybenzenecarboximidoate & - & \\
\hline Methyl 8-[(1R,2R)-2-[(1S,2R)-2 & - & \\
\hline
\end{tabular}

There are many studies in the literature examining these parameters. For instance, Cho et al. (2003) investigated volatile aroma components in Shiitake mushroom (Lentinula edodes) at different maturity stages, including young, mature and old mushrooms and differences were identified. These differences were both in the number of compounds and in the decrease or increase of certain groups of compounds. Li et al. (2019) examined the effect of growing mixtures consisting of different agricultural wastes on the volatile aroma composition of Shiitake mushroom and again differences were observed in both the number of compounds and their ratios. Wu and Wang (2000) compared the aroma components of fresh and dried
Shiitake mushroom and found differences. Politowicz et al. (2018) found that drying techniques are effective on aroma components in Shiitake mushroom. Therefore, differences obtained from our study may have occurred due to these reasons. Within our knowledge, there is no study on the effect of growing mixtures on the volatile profile in Maitake mushroom grown in different growing substrate mixtures.

Among the compounds obtained in this study, 3octanone, octanal, 3-octanol and 1-octen-3-ol are eightcarbon compounds. Their ratios were $37.02 \%$ and $27.19 \%$ in S4 and S5 mixtures, respectively. Eight carbon compounds are important in forming of taste and smell of 
mushrooms. The percentage of eight-carbon compounds, especially 1-octen-3-ol, has been found to be high is generally in wild mushrooms (Taşkın, 2013; Taşkın et al., 2013; Bozok et al., 2015; 2018; Taşkın et al., 2019). However, there is information in the literature that this compound could not be detected in some wild mushroom species, albeit rarely. For example, Taşkın et al. (2019) detected high 1-octen-3-ol in wild-collected cedar mushroom (Tricholoma anatolicum), however they could not record 1-octen-3-ol in T. caligatum examined in the same study.

1-octen-3-ol is also called mushroom alcohol. In this presented study, 1-octen-3-ol was found to be at low level. However another eight-carbon compound 3-octanone was found to be high. In the comparison of growing mixtures, a higher result was obtained from $\mathrm{S} 4$ mixture containing oak sawdust for eight-carbon compounds than S5 containing poplar sawdust. Similar results were observed by Baktemur et al. (2020), who investigated the effects of different agricultural wastes on the aroma composition of Shiitake mushroom. It was determined that growing mixtures containing oak sawdust produce a higher number of eight-carbon compounds than those containing poplar sawdust. Another compound obtained at a high percentage in the study was 4-nonanone classified a ketone. The ratio of this compound was found as $35.17 \%$ and $28.13 \%$ in the S4 containing oak sawdust and S5 containing poplar sawdust, respectively. Similar results were also determined by Baktemur et al. (2020). Oak sawdust has been found to be more successful than poplar sawdust. The taste and odour definitions of the compounds obtained in this study were presented in Table 3.

\section{Conclusion} below:

The findings obtained from the study were summarized

- $\quad$ Yield values were $55.02 \mathrm{~g} \mathrm{~kg} \mathrm{bag}^{-1}$ and $124.82 \mathrm{~g} \mathrm{~kg}$ $\mathrm{bag}^{-1}$ in S4 and S5 growing mixtures, respectively.

- Total bioactive amounts of frozen and dry samples obtained from S4 were calculated as $5.06 \pm 0.14$ and $17.47 \pm 1.00 \mathrm{mg}$ GAE $\mathrm{g}^{-1} \mathrm{DM}$, respectively, and $3.45 \pm 0.07$ and $29.26 \pm 1.34 \mathrm{mg} \mathrm{GAE} \mathrm{g}^{-1} \mathrm{DM}$ in S5, respectively. It is seen that values increase with drying in both growing mixtures.

- $\quad$ DPPH analysis data of frozen and dry samples for S4 and S5 were found as $7.99 \pm 0.08$ and $8.19 \pm 0.05 \mu \mathrm{mol}$ $\mathrm{TE} \mathrm{g}^{-1} \mathrm{DM}(\mathrm{S} 4)$ and $8.07 \pm 0.09$ and $8.20 \pm 0.06 \mu \mathrm{mol}$ TE $\mathrm{g}^{-1}$ DM (S5). FRAP results were determined as

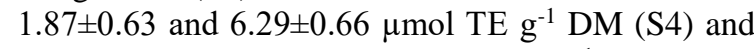
$4.24 \pm 0.44$ and $6.45 \pm 0.16 \mu \mathrm{mol} \mathrm{TE} \mathrm{g}^{-1} \mathrm{DM}$ (S5). Antioxidant activity findings of samples grown in S5 were higher than in S4. In the antioxidant activity analysis methods, data obtained by DPPH method were higher than those obtained by FRAP method. While the drying process did not show a significant enhancing effect on bioactives that can reduce the hydrogen ion, those that reduce the iron ion increased about 2-fold.

- In S4 and S5 growing mixtures, 22 and 32 volatile aroma components were detected, respectively.
While aldehydes, alcohols, volatile acids and other components were detected higher in S5, hydrocarbons and ketones were found to be higher in S4. Eight-carbon compounds were $37.02 \%$ and $27.19 \%$ in S4 and S5, respectively. 3-octanone was found to be the highest eight-carbon compound and also the second highest for all compounds obtained from the study. The compound determined at the highest percentage was 4-nonanone $(35.17 \%$ in S4, and $28.13 \%$ in S5). The most common compound group was detected to be ketone, which includes 3octanone and 4-nonanone. In the growing mixtures comparison, S4 containing oak sawdust was more efficient for eight-carbon compounds than the S5 containing poplar sawdust.

Maitake mushroom is almost an unknown species in Turkey. Learning the cultivation of this species, revealing its nutritional value and medical importance will be beneficial for the producers and consumers of Turkey. The confidence of consumers in food products, whose nutritional value and medical importance have been proven by scientific studies, rises. Diversity of cultivated mushroom species in the country may be increased via the introduction and wide cultivation of new mushroom species. With this study, the antioxidant activity and volatile aroma composition of Maitake mushroom have been revealed. At the same time, first experiences have been gained in terms of cultivation.

The recommendations after this study can be listed as increasing number and types of agricultural wastes that can be used for different regions of Turkey and revealing nutritional value and medical importance of Maitake mushroom using different analyzes.

\section{Acknowledgment}

The authors would like to thank to Çukurova University Scientific Research Projects Coordinating Office (Project code: FYL-2019-11232) for supporting this study financially and Mushroom Spawn Lab of Penn State University (US) for sending Maitake strain.

\section{References}

Aghraz A, Gonçalves S, Rodríguez-Solana R, AitDra L, Di Stefano V, Dugo G, Cicero N, Larhsini M, Markouk M, Romano A. 2018. Antioxidant activity and enzymes inhibitory properties of several extracts from two Moroccan Asteraceae species. South African Journal of Botany, 118: 58-64. doi: 10.1016/j.sajb.2018.06.017

Aisala H, Sola J, Hopia A, Linderborg KM, Sandell M. 2019. Odorcontributing Volatile Compounds of Wild Edible Nordic Mushrooms Analyzed with HS-SPME-GC-MS and HSSPME-GC-O/FID. Food Chemistry, 283: 566-578. doi: 10.1016/j.foodchem.2019.01.053

Badcock EC. 1939. Preliminary account of the odour of wooddestroying fungi in culture. Transactions of the British Mycological Society, 22(2): 188-98. doi: 10.1016/S00071536(39)80024-9

Baktemur G, Çelik ZD, Kara E, Taşkın H. 2020. The Effect of Different Agricultural Wastes on Aroma Composition of Shiitake (Lentinula edodes (Berk.) Pegler) Mushroom. Turkish Journal of Agriculture - Food Science and Technology, 8(7): 1540-1547. doi: 10.24925/turjaf.v8i7. 1540-1547.3415 
Barreto SM, Lopez MV, Levin L. 2008. Effect of culture parameters on the production of the edible mushroom Grifola frondosa (maitake) in tropical weathers. World Journal of Microbiology and Biotechnology, 24: 1361-1366. doi: 10.1007/s11274-007-9616-Z

Bennett LE, Jegasothy H, Konczak I, Frank D, Sudharmarajan S, Clingeleffer PR. 2011. Total polyphenolics and anti-oxidant properties of selected dried fruits and relationships to drying conditions. Journal of Functional Foods, 3(2): 115-124. doi: 10.1016/j.jff.2011.03.005

Bozok F, Kafkas E, Büyükalaca S. 2018. Türkiye'nin Adana İlinden Toplanan Suillus collinitus (Fr.)'un Uçucu Aroma Kompozisyonunun Belirlenmesi. Türk Tarım-Gida Bilim ve Teknoloji Dergisi, 6(4): 486-489. doi: 10.24925/turjaf. v6i4.486-489.1802

Bozok F, Zarifikhosroshahi M, Kafkas E, Taşkın H, Büyükalaca S. 2015. Comparison of Volatile Compounds of Fresh Boletus edulis Bull:Fr. and Boletus pinophilus Pilât in Marmara Region of Turkey. Notulae Botanicae Horti Agrobotanici Cluj-Napoca, 43(1): 192-195. doi: 10.15835/nbha4319731

Butkhup L, Samappito W, Jorjong S. 2018. Evaluation of bioactivities and phenolic contents of wild edible mushrooms from northeastern Thailand. Food Science and Biotechnology, 27(1): 193-202. doi: 10.1007/s10068-017-0237-5

Chang ST, Miles PG. 2004. Mushrooms: cultivation, nutritional value, medicinal effect, and environmental impact. $2^{\text {nd }}$ ed., CRC Press, p. 480.

Cho DB, Seo HY, Kim KS. 2003. Analysis of the Volatile Flavor Compounds Produced during the Growth stages of the Shiitake mushrooms (Lentinus edodes). Journal of Food Science and Nutrition, 8: 306-314.

Cho IH, Lee SM, Kim SY, Choi HK, Kim KO, Kim YS. 2007. Differentiation of aroma characteristics of pine-mushrooms (Tricholoma matsutake Sing.) of different grades using gas chromatography-olfactometry and sensory analysis. Journal of Agricultural and Food Chemistry, 55(6): 2323-2328. doi: 10.1021/jf062702z

Curioni PMG, Bosset CO. 2002. Key odorants in various cheese types as determined by gas chromatography-olfactometry. International Dairy Journal, 12(12): 959-984. doi: 10.1016/S0958-6946(02)00124-3

Culleré L, Ferreira V, Chevret B, Venturini ME, Sánchez-Gimeno AC, Blanco D. 2010. Characterisation of aroma active compounds in black truffles (Tuber melanosporum) and summer truffles (Tuber aestivum) by gas chromatographyolfactometry. Food Chemistry, 122(1): 300-306. doi: 10.1016/j.foodchem.2010.02.024

Friedrich JE, Acree TE. 1998. Gas chromatography olfactometry $(\mathrm{GC} / \mathrm{O})$ of dairy products. International Dairy Journal, 8: 23541. doi: 10.1016/S0958-6946(98)80002-2

Fuller GH, Steltenkamp R, Tisserend GA. 1964. The Gas Chromatography with Human Sensor: Perfumer Model. Annals of the New York Academy of Sciences, 116: 711-724. doi: 10.1111/j.1749-6632.1964.tb45106.x

Gallois A, Gross B, Langlois D, Spinnler HE, Bruneire P. 1990. Influence of culture conditions on production of flavour compounds by 29 ligninolytic Basidiomycetes. Mycological Research, 94(4): 494-504. doi: 10.1016/S09537562(10)80010-3

Güneşer O, Yüceer YK. 2010. Gıdalarda Aroma Maddelerinin Belirlenmesinde Gaz Kromatografisi-Olfaktometri (GCO) Tekniklerinin Kullanılması. Gida, 35(5): 371-378.

Halliwell B, Gutteridge JMC. 1984. Oxygentoxicity, oxygenradicals, transition metals and disease. Biochemical Journal, 219: 1-14. doi: 10.1042/bj2190001

Hış1 Y. 2004. Enstrümental Gıda Analizleri-II. Ege Üniversitesi Mühendislik Fakültesi Ders Kitapları, Yayın No: 30, İzmir.

Hsieh C, Yang F. 2004. Reusing soy residue for the solid-state fermentation of Ganoderma lucidum. Bioresource Technology, 91: 105-9. doi: 10.1016/s0960-8524(03)00157-3
Jong SC, Birmingham JM. 1993. Mushrooms as a source of natural flavor and aroma compounds. In: Chang ST, Buswell JA, Chiu SW (editors). Mushroom Biology and Mushroom Production. Pekin, Chinese University Press. pp. 345-366.

Li W, Wang J, Chen W, Yang Y, Zhang J, Feng J, Yu H, Li Q. 2019. Analysis of volatile compounds of Lentinula edodes grown in different culture substrate formulations. Food Research International, 125. doi: 10.1016/j.foodres.2019. 108517

Li Y, Ma D, Sun D, Wang C, Zhang J, Xie Y, Guo T. 2015. Total phenolic, flavonoid content, and antioxidant activity of flour, noodles, and steamed bread made from different colored wheat grains by three milling methods. The Crop Journal, 3(4): 328-334. doi: 10.1016/j.cj.2015.04.004

Lopetcharat K, Mcdaniel M. 2005. Sensory analysis of foods. In: Ötleş S (editor). Methods of Analysis of Food Components and Additives. Boca Raton, FL: CRC Press, Taylor \& Francis Group, pp. 262-295. ISBN 0-8493-1647-2.

Maga JA. 1976. The potential of certain fungi as sources for natural flavor compounds. Chemical Sens, 2(2): 255-262. doi: 10.1093/chemse/2.2.255

Mau JL, Chang CN, Huang SJ, Chen CC. 2004. Antioxidant properties of methanolic extracts from Grifola frondosa, Morchella esculenta and Termitomycesal buminosus mycelia. Food Chemistry, 87(1): 111-118. doi: 10.1016/j.foodchem.2003.10.026

Mau JL, Lin HC, Song SF. 2002. Antioxidant properties of several specialty mushrooms. Food Research International, 35(6): 519-526. doi: 10.1016/S0963-9969(01)00150-8

Mayol AR, Acree TE. 2001. Advances in gas chromatographyolfactometry. In: Leland JV, Schieberle P, Buetterner A, Acree TE (editors). Gas Chromatography-Olfactometry the State of the Art. Washington DC: ACS Symp Ser 782, American Chemical Society. pp. 1-11.

Montoya S, Orrego CE, Levin L. 2012. Growth, fruiting and lignocellulolytic enzyme production by the edible mushroom Grifola frondosa (maitake). World Journal of Microbiology and Biotechnology, 28: 1533-41. doi: 10.1007/s11274-0110957-2

Muhammad Ezzudin R, Rabeta MS, Shaida Fariza S, Leong Ooi K, Nurul Shafiqah H. 2019. Primary and secondary antioxidant activities of nine edible mushrooms species. Food Research, 3(1): 14-20. doi: 10.26656/fr.2017.3(1).077

Palazzolo E, Saiano F, Laudicina VA, Gargano ML, Venturella G. 2017. Volatile organic compounds in wild fungi from Mediterranean forest ecosystems. Journal of Essential Oil Research, 29(5): 385-390. doi:g/10.1080/10412905.2017.1302896

Pionnier E, Hugelshofer D. 2006. Characterisation of key odorant compounds in creams from different origins with distinct flavours. Developments in Food Science, 43: 233-236. doi: 10.1016/S0167-4501(06)80056-7

Politowicz J, Lech K, Lipan L, Figiel A, Carbonell-Barrachina ÁA. 2018. Volatile composition and sensory profile of shiitake mushrooms as affected by drying method. Journal of the Science of Food and Agriculture, 98(4): 1511-1521. doi: $10.1002 /$ jsfa.8622

Qi HM, Zhang QB, Zhao TT, Chenc R, Zhang H, Niu XZ. 2005. Antioxidant activity of different sulfate content derivatives of polysaccharide extracted from Ulva pertusa (Chlorophyta) in vitro. International Journal of Biological Macromolecules, 37: 195-199. doi: 10.1016/j.ijbiomac.2005.10.008

Ramarathnam N, Osawa T, Ochi H, Kawakishi S. 1995. The contribution of plant food antioxidants to human health. Trends in Food Science \& Technology, 6: 75-82. doi: 10.1016/S0924-2244(00)88967-0

Rapior S, Cavalie S, Croze P, Andary C, Pelissier Y, Bessiere JM. 1996. Volatile Components of Ten Frozen Mushrooms (Basidiomycetes). Journal of Essential Oil Research, 8(1): 63-66. 
Reineccius GA. 1994. Flavor analysis. In: Reineccius GA (editor). Source Book of Flavors. New York, Chapman \& Hall. pp.24-60.

Sato M, Miyagi A, Yoneyama S, Gisusi S, Tokuji Y, KawaiYamada M. 2017. CE-MS-based metabolomics reveals the metabolic profile of maitake mushroom (Grifola frondosa) strains with different cultivation characteristics. Bioscience, Biotechnology, and Biochemistry, 81(12): 2314-2322. doi:10.1080/09168451.2017.1387049

Schindler J, Schmid RD. 1982. Fragrance and aroma chemicals. Microbial synthesis and enzymatic transformation. A review. Process Biochemistry, 17(5): 2-8.

Selli S, Canbas A, Cabaroglu T, Erten H, Günata Z. 2006. Aroma components of $\mathrm{cv}$. Muscat of Bornova wines and influence of skin contact treatment. Food Chemistry, 94(3): 319-326. doi: 10.1016/j.foodchem.2004.11.019

Shin YJ, Lee SC. 2014. Antioxidant activity and $\beta$-glucan contents of hydrothermal extracts from maitake (Grifola frondosa). Food Science and Biotechnology, 23(1): 277-282. doi: 10.1007/s10068-014-0038-z

Song B, Ye J, Sossah FL, Li C, Li D, Meng L, Xu S, Fu Y, Li Y. 2018. Assessing the effects of different agro-residue as substrates on growth cycle and yield of Grifola frondosa and statistical optimization of substrate components using simplex-lattice design. AMB Express, 8: 46. doi: 10.1186/s13568-018-0565-8

Svagelj M, Berovic M, Boh B, Menard A, Simcic S, Wraber B. 2008. Solid-state cultivation of Grifola frondosa (Dicks: Fr) S.F. Gray biomass and immunostimulatory effects of fungal intra- and extracellular $\beta$-polysaccharides. New Biotechnology, 25(2-3): 150-156. doi: 10.1016/j.nbt.2008.08.006

Szydłowska-Czerniak A, Dianoczki C, Recseg K, Karlovits G, Szłyk E. 2008. Determination of antioxidant capacities of vegetable oils by ferric-ion spectrophotometric methods. Talanta, 76(4): 899-905. doi: 10.1016/j.talanta.2008.04.055

Tabata T, Yamasaki Y, Ogura T. 2004. Comparison of Chemical Compositions of Maitake (Grifola frondosa (Fr.) S. F. Gray) Cultivated on Logs and Sawdust Substrate. Food Science and Technology Research, 10(1): 21-24. doi: 10.3136/fstr.10.21

Taşkın H. 2013. Detection of Volatile Aroma Compounds of Morchella by Headspace Gas Chromatography Mass Spectrometry (HS-GC/MS). Notulae Botanicae Horti Agrobotanici Cluj-Napoca, 41(1): 122-125. doi: 10.15835/nbha4118344
Taşkın H, Baktemur G, Kafkas E, Büyükalaca S. 2013. Gyromitra Mantarının Uçucu Aroma Bileşenlerinin Tepe Boşluğu Gaz Kromotografisi Kütle Spektroskopisi (HSGC/MS) Tekniği ile Belirlenmesi. Türk Tarım-Gıda Bilim ve Teknoloji Dergisi, 1(1): 8-11.

Taşkın H, Çelik ZD, Bozok F, Cabaroğlu T, Büyükalaca S. 2019. First Report on Volatile Composition of Tricholoma anatolicum in Comparison with Tricholoma caligatum. Records of Natural Products, 6: 446-455. doi: 10.25135/rnp.122.18.12.1095

Tian Y, Zhao Y, Huang J, Zeng H, Zheng B. 2016. Effects of different drying meth-ods on the product quality and volatile compounds of whole shiitake mushrooms. Food Chemistry, 197: 714-22. doi: 10.1016/j.foodchem.2015.11.029

Xu X, Xu R, Jia Q, Feng T, Huang Q, Ho CT, Song S. 2019. Identification of dihydro- $\beta$-ionone as a key aroma compound in addition to C8 ketones and alcohols in Volvariella volvacea mushroom. Food Chemistry, 293: 333-339. doi: 10.1016/j.foodchem.2019.05.004

Van Ruth SM. 2001. Methods for gas chromatographyolfactometry: a review. Biomolecular Engineering, 17: 121-128. doi: 10.1016/S13890344(01)00070-3

Wu CM, Wang Z. 2000. Volatile Compounds in Fresh and Processed Shiitake Mushrooms (Lentinus edodes Sing.). Food Science and Technology Research, 6(3): 166-170. doi: 10.3136/fstr.6.166

Yeh JY, Hsieh LH, Wu KT, Tsai CF. 2011. Antioxidant Properties and Antioxidant Compounds of Various Extracts from the Edible Basidiomycete Grifola frondosa (Maitake). Molecules, 16(4): 3197-3211. doi: 10.3390/molecules16043197

Yıldız O, Can Z, Laghari AQ, Şahin H, Malkoç M. 2015. Wild Edible Mushrooms as a Natural Source of Phenolics and Antioxidants. Journal of Food Biochemistry, 39(2): 148-154. doi: $10.1111 /$ jbc. 12107

Zhang H, Pu D, Sun B, Ren F, Zhang Y, Chen H. 2018. Characterization and comparison of key aroma compounds in raw and dry porcini mushroom (Boletus edulis) by aroma extract dilution analysis, quantitation and aroma recombination experiments. Food Chemistry, 258: 260-268. doi: 10.1016/j.foodchem.2018.03.056

Zhou J, Feng T, Ye R. 2015. Differentiation of Eight Commercial Mushrooms by Electronic Nose and Gas ChromatographyMass Spectrometry. Journal of Sensors. doi: https://doi.org/10.1155/2015/3740 